\title{
Evaluating a Social Media Campaign for a Parent Educational Video on Bronchiolitis
}

\section{Hyelin Sung, ${ }^{1}$ Lisa Hartling, ${ }^{2}$ Hannah Brooks, ${ }^{1}$ and Shannon Scott ${ }^{1}$}

${ }^{1}$ Faculty of Nursing, University of Alberta, Edmonton, Alberta

${ }^{2}$ Department of Pediatrics, University of Alberta, Edmonton, Alberta

Corresponding author: hyelin1@ualberta.ca

\section{ABSTRACT}

Bronchiolitis, or lower airway swelling, is a common cause of pediatric hospital admissions. Parents have expressed wishes for more information regarding bronchiolitis but had difficulty finding reliable information, suggesting the need for more effective and easily accessible information resources. Knowledge translation (KT) tools like videos provide research-based information and may be conveniently disseminated to large audiences through social media. The purpose of this project was to evaluate the effectiveness of a social media campaign to promote a video on bronchiolitis. A social media campaign was conducted from 14 October to 30 November 2019. User interactions were recorded for the Facebook and Twitter accounts, website, and YouTube of Evidence in Child Health to Enhance Outcomes (ECHO), Alberta Research Centre for Health Evidence (ARCHE), and Translating Emergency Knowledge for Kids (TREKK). Baseline metrics were collected from 1 August to 30 September 2019 and post-campaign metrics were collected from 1 December 2019 to 31 March 2020. Mean monthly changes, standard deviations, and percent changes between periods were generated for the baseline, campaign, and post-campaign periods. Overall, there was a visible increase in user interactions throughout the campaign period. There was an overall downward trend in user interactions following the campaign. These findings suggest that social media may be a useful method of KT tool dissemination when consistently used. The downward trend post-campaign highlights the need for further research to investigate methods to maintain continuous interaction following a campaign.

\section{Background}

Bronchiolitis, or lower airway swelling, is a common cause for hospital admissions in the first year of life (Nair et al., 2010; Ricci et al., 2015). One in five infants are affected by bronchiolitis and $2-3 \%$ require hospitalization (Ricci et al., 2015). It is commonly caused by the respiratory syncytial virus (RSV) (Coffin, 2005; Nicolai et al., 2013). Bronchiolitis is usually resolved without treatment, however, severe complications like pneumonia and empyema may occur. This may cause distress for children and caregivers (Miller et al., 2013).

A clinical practice guideline for bronchiolitis management is supportive care, but variation in clinical practice often leads to overuse of unnecessary tests and treatments by health care providers (HCPs) (Florin et al., 2014; Ricci et al., 2015). Lack of concrete treatments, symptom presentation, and potential for invasive treatments may leave parents feeling helpless about how to

SPECTRUM | INTERDISCIPLINARY UNDERGRADUATE RESEARCH 
reduce their child's suffering (Cabral et al., 2014). Many parents suffer psychologically and emotionally when their child is admitted to a hospital (Kamban \& Svavarsdottir, 2013; Leidy et al., 2005). Campbell et al. (2019) discovered parents wished for more information about bronchiolitis, but many had difficulty finding reliable information when their child was ill. Insufficient information, especially information targeted to the home environment, may heighten caregivers' feelings of fear, isolation, and helplessness (Gates et al., 2019). These findings suggest that more effective information resources are needed.

Knowledge translation (KT) focuses on putting research to work. Arts-based KT tools, such as videos, provide understandable and accessible health information to help caregivers make informed decisions and shape treatment expectations (Slater et al., 2003). They may help reduce unnecessary health care utilization and caregiver anxiety, ultimately improving child health outcomes (Bjornson et al., 2004; Chin et al., 2002; Graham \& Tetroe, 2007; Kaushal et al., 2001; Langley et al., 1997).

Social media may be a convenient method of KT tool dissemination to the general population. $80 \%$ internet users in the U.S. search for online health resources and $74 \%$ of internet users use social media (O'Kelly et al., 2017; Ventola, 2014). Facebook and Twitter have 1.13 billion and 313 million estimated daily users, respectively (O'Kelly et al., 2017). The wide reach of social media to various populations across the world may help improve access to reliable, research-based health information and education resources, such as KT tools (Moorhead et al., 2013; Ventola, 2014).

Translating Evidence in Child Health to Enhance Outcomes $(\mathrm{ECHO})$ is a research program aiming to better pediatric health outcomes through KT (ECHO Research, 2020a). The Alberta Research Centre for Health Evidence (ARCHE) utilizes knowledge synthesis to support the development of evidence-based practice (University of Alberta, 2021). Translating Emergency Knowledge for Kids (TREKK) is a knowledge mobilization network striving to improve pediatric emergency care by addressing knowledge gaps (TREKK, 2021a). ECHO, ARCHE, and TREKK collaborate to develop and disseminate theory about child health specific KT processes and KT tools to improve child health outcomes.

The Institute of Human Development, Child and Youth Health (IHDCYH) supports child health research (Canadian Institutes of Health Research, 2021). The IHDCYH Talks program seeks to improve KT of child health research. The program includes an annual IHDCYH Talks Video Competition where participants submit videos presenting evidence-based information that positively impacts the health of children to a lay audience. The competition aims to outline research within IHDCYH's mandate to improve KT and showcase the impact evidence has on Canadians' health.

Social media, websites, and in person promotions were used to disseminate and promote an evidence-based video about bronchiolitis (IHDCYH Talks, 2019) created by ECHO, ARCHE, and TREKK. The video was submitted to the IHDCYH competition and strived to provide understandable research-based information to parents on how to best manage their child's bronchiolitis. A social media campaign was implemented with the goals of: (1) increasing the reach and views of the bronchiolitis video, (2) increasing traffic to website KT tool sections, and (3) engaging caregivers in the $\mathrm{ECHO}$, ARCHE, and TREKK networks. The purpose of this project was to evaluate the effectiveness of a social media campaign to promote a video on bronchiolitis.

\section{Methods}

\section{Campaign Summary}

The social media campaign was 7 weeks long and took place from 14 October to 30 November 2019 (see Table 1). It was followed by a post-campaign period from 1 December 2019 - 31 March 2020. The campaign period was supplemented by in-person promotions with champions and stakeholders as well as promotion on the ECHO and TREKK websites. The primary audiences were Canadian parents and caregivers. The secondary audiences included pediatric emergency HCPs, general HCPs, and international stakeholders. 
Table 1: Detailed weekly campaign schedule

\begin{tabular}{|c|c|c|}
\hline Week & Topics & Frequency \\
\hline $\begin{array}{l}\text { 1. October 14-20, } \\
2019\end{array}$ & $\begin{array}{ll}\text { - Introductory content about KT tools and their } \\
\text { development cycle } \\
\text { - Introduce new urinary tract infection (UTI) and } \\
\text { bronchiolitis tools }\end{array}$ & $\begin{array}{l}2 \text { Twitter posts on each account } \\
2 \text { Facebook posts on ECHO \& } \\
\text { TREKK accounts } \\
\text { TREKK e-update }\end{array}$ \\
\hline $\begin{array}{l}\text { 2. October 21-27, } \\
2019\end{array}$ & $\begin{array}{ll}\text { - } & \text { Promotion of IHDCYH contest } \\
\text { - Introductory content about KT tools and their } \\
\text { - } \\
\text { - Inforelopment cycle }\end{array}$ & $\begin{array}{l}2 \text { Twitter posts on each account } \\
1 \text { Facebook post on ECHO \& } \\
\text { TREKK accounts } \\
1 \text { Instagram post on UofA } \\
\text { Nursing \& TREKK accounts }\end{array}$ \\
\hline $\begin{array}{l}\text { 3. October } 28- \\
\text { November } 3,2019\end{array}$ & $\begin{array}{ll}\text { - } & \text { Promotion of IHDCYH contest } \\
\text { - } & \text { Introductory content about TREKK parent tools } \\
& \text { (needs assessment graphics etc.) } \\
\text { - } & \text { Key messages (starting November } 1^{\text {st }} \text { ) }\end{array}$ & $\begin{array}{l}2 \text { Twitter posts on each account } \\
\text { 1-2 Facebook post on ECHO \& } \\
\text { TREKK accounts } \\
1 \text { Instagram post on TREKK } \\
\text { TREKK e-update }\end{array}$ \\
\hline $\begin{array}{l}\text { 4. November 4-10, } \\
2019\end{array}$ & $\begin{array}{ll}- & \text { Key messages } \\
\text { - } & \text { IHDCYH contest information }\end{array}$ & $\begin{array}{l}\text { 2-3 Twitter posts on each } \\
\text { account } \\
\text { 1-2 Facebook post on ECHO \& } \\
\text { TREKK accounts } \\
1 \text { Instagram post on TREKK } \\
\text { TREKK email to stakeholders } \\
\text { In-person promotion at } \\
\text { conferences }\end{array}$ \\
\hline $\begin{array}{l}\text { 5. November 11-17, } \\
2019\end{array}$ & $\begin{array}{ll} & \text { Key messages } \\
\text { - } & \text { IHDCYH contest information }\end{array}$ & $\begin{array}{l}\text { 2-3 Twitter posts on each } \\
\text { account } \\
1 \text { Facebook post on ECHO \& } \\
\text { TREKK accounts } \\
1 \text { Instagram post on UofA } \\
\text { Nursing \& TREKK accounts }\end{array}$ \\
\hline $\begin{array}{l}\text { 6. November 18-24, } \\
2019\end{array}$ & $\begin{array}{ll}\text { - } & \text { Key messages } \\
\text { - } & \text { IHDCYH contest information }\end{array}$ & $\begin{array}{l}3 \text { Twitter posts on each account } \\
1 \text { Facebook post on ECHO \& } \\
\text { TREKK accounts } \\
1 \text { Instagram post on TREKK } \\
\text { In-person promotion }\end{array}$ \\
\hline $\begin{array}{l}\text { 7. November 25-30, } \\
2019\end{array}$ & - Key messages & $\begin{array}{l}3 \text { Twitter posts on each account } \\
2 \text { Facebook post on ECHO \& } \\
\text { TREKK accounts } \\
1 \text { Instagram post on UofA } \\
\text { Nursing \& TREKK accounts }\end{array}$ \\
\hline
\end{tabular}


Throughout the campaign, the Twitter and Facebook accounts, interactions with the bronchiolitis video on YouTube, and interactions with the $\mathrm{ECHO}$ and TREKK websites were monitored.

\section{Digital Media Platforms Used}

Facebook and Twitter were chosen as they are platforms that ECHO, ARCHE and TREKK are established on. As well, Facebook has been noted to be the most popular social media tool amongst Canadian adults (Gruzd et al., 2018). Facebook and Twitter posts included text sections accompanied by a graphic (see Figure 1).

Bronchiolitis is a viral infection commonly caused by RSV (respiratory syncytial virus). Common symptoms include: fever, runny nose/cough, wheezing, and dehydration. Learn more about bronchiolitis by reading our infographic and ebook available at bit.ly/bronchio or by watching our video at bit.Iy/2019/HDCYH. (Please be sure to LIKE our video on YouTube to help us win this year's $\mathrm{CIHR}$ IHDCYH Competition!)

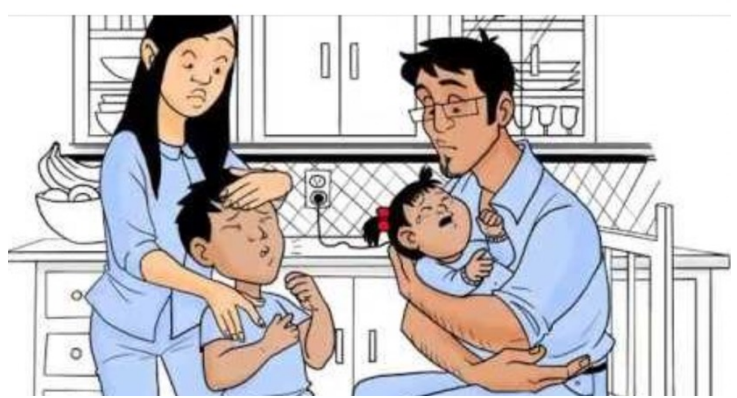

Note: From ECHO Facebook (ECHO Research, 2019)

Figure 1: Representative Post

\section{Facebook}

Fifteen posts were each published on the TREKK (Translating Emergency Knowledge for Kids [TREKK], n.d.a) and ECHO (ECHO Research, n.d.) Facebook pages. The posts on Facebook were intended to disseminate the bronchiolitis video to a wider audience, promote the IHDCYH competition, and promote other $\mathrm{KT}$ tools developed by $\mathrm{ECHO}, \mathrm{ARCHE}$ and TREKK. Contents of Facebook posts included: promotion of the IHDCYH Talks Competition, information about existing $\mathrm{KT}$ tools, a traceable bit.ly link to the bronchiolitis video, and information about bronchiolitis based on highlighted key messages from the video.

\section{Twitter}

Three to nine tweets per week resulting in 73 tweets in total were published on the ECHO, ARCHE, and TREKK
Twitter accounts (Scott, n.d.; ARCHE, n.d.; TREKK, n.d.b). Two tweets were published per account for weeks 1-3, 2-3 tweets for weeks 4-5, and 3 tweets for weeks 6-7. Tweets included bronchiolitis information based on the key messages, traceable links to the bronchiolitis video and other KT tools, information about existing tools, and information on the IHDCYH competition. Each post contained an image. These included screen captures from the bronchiolitis video, an infographic with information about the KT tools, and an infographic with information regarding the IHDCYH competition.

Website

A blog post was published on the ECHO website (ECHO Research, 2020a). It provided backgrounder details such as key points from the bronchiolitis video and information on the IHDCYH competition. Links to other existing KT tools were included. A link to the bronchiolitis video was also posted to the TREKK (TREKK, 2021a) and ECHO websites on the 'Parent/Family' page and 'Tools' page, respectively. Interactions with the websites were monitored using website analytic data. Bit.ly links were created and monitored for the 'Parent/Family' TREKK webpage, the 'Tools' ECHO webpage, and the YouTube video.

\section{YouTube}

The bronchiolitis video was submitted to the IHDCYH competition and was uploaded to the Canadian Institute of Health Research (CIHR) YouTube page in November 2019. YouTube video analytics like number of video views and viewer demographics were collected in May 2020 for the period of November 2019 to March 2020.

\section{Stakeholder and Audience Engagement}

Digital Stakeholder Engagement

Influential stakeholders were tagged in Twitter posts to help increase audience engagement. As well, stakeholders and champions were emailed information on the bronchiolitis video and were given a backgrounder, sample pre-crafted social media posts and graphics, and newsletter blurbs for reference. 
In-person Engagement

To increase stakeholder and general audience engagement, in-person promotions were conducted using printed promotional materials. Materials were distributed to stakeholders and audiences across a Western Canadian university and children's hospital research institute. In-person promotions were also conducted at academic research conferences in October and November 2019.

\section{End-user Involvement}

Parents, caregivers, family members, and HCPs were directly involved in the development of the bronchiolitis video and other KT tools promoted in this campaign. The use of images, clear and plain language, and engagement with child health stakeholders helped to ensure the campaign messages could be easily directed towards our primary audience and end-users: parents and caregivers.

\section{Data Collection}

Indicators of engagement with the ECHO, ARCHE, and TREKK social media accounts, websites, and the bronchiolitis video were recorded throughout the campaign. Data was stored in a Microsoft Office Excel workbook.

Baseline Twitter followers, profile visits, and impressions as well as Facebook likes and post reach were recorded from August to September 2019 for ECHO, TREKK, and ARCHE accounts. Twitter metrics were collected from the Twitter activity dashboard to measure user interactions. These included number of followers (times a user followed the account) impressions per month (times a user viewed the tweets), and profile visits (times a user visited the profile). Facebook metrics were collected from the Facebook Insights dashboard and included page likes (times a user liked the account) and average post reach (number of people who saw the post on their personal feeds).

Baseline website data including number of visitors were recorded for the ECHO and TREKK websites from August to September 2019. Monthly metrics were collected on the first day of the following month. Website metrics were collected from the web host platform and included number of website visits, number of visits to the 'Tools' page (ECHO Research, 2020b; TREKK, 2021b), and tool views (times a user views a tool). Bit.ly was used to collect metrics on the number of times a user clicked a specific link either to the ECHO or TREKK websites or to the bronchiolitis video. YouTube user interactions were recorded using YouTube's analytics from 1 to 30 November 2019 for the campaign period and 1 December 2019 to 31 March 2020 for the post-campaign period. Metrics recorded included the number of video views (times a user viewed the video), watch time (total time video has been viewed), average view duration (average time users view the video), and impressions for the videos (times a user viewed the video thumbnail).

\section{Data Analysis}

Descriptive statistics were generated using Microsoft Office Excel. Mean monthly changes and standard deviations were generated for the time periods of pre-campaign baseline (August-September 2019), campaign (October-November 2019), and postcampaign (December 2019-March 2020) for the ECHO, ARCHE, and TREKK Facebook, Twitter, and website user interaction measures. Percent differences between pre-campaign to campaign and campaign to postcampaign were generated using mean changes. Since the YouTube video and the Bit.ly links were uploaded and generated at the beginning of the campaign, no baseline metrics were available. Campaign (OctoberNovember 2019 for Bit.ly and November 2019 for YouTube) and post-campaign (December 2019-March 2020) means were generated. Percent differences were generated between the two periods.

\section{Results}

Interactions with Twitter Accounts

Table 2 depicts the average monthly user interactions with ECHO, ARCHE, and TREKK Twitter accounts.

@echoKTresearch

At baseline, the ECHO Twitter account had an average of 19.5 new followers per month. Throughout the 
Table 2: Average user interactions with Twitter accounts per month

\begin{tabular}{|c|c|c|c|c|c|c|c|c|c|}
\hline \multirow{2}{*}{$\begin{array}{l}\text { Social } \\
\text { media }\end{array}$} & \multicolumn{3}{|c|}{ ECHO Twitter, Mean (SD) } & \multicolumn{3}{|c|}{ TREKK Twitter, Mean (SD) } & \multicolumn{3}{|c|}{ ARCHE Twitter, Mean (SD) } \\
\hline & $\begin{array}{c}\text { New } \\
\text { Followers }\end{array}$ & $\begin{array}{c}\text { Profile } \\
\text { visits }\end{array}$ & Impressions & $\begin{array}{c}\text { New } \\
\text { Followers }\end{array}$ & $\begin{array}{l}\text { Profile } \\
\text { visits }\end{array}$ & Impressions & $\begin{array}{c}\text { New } \\
\text { Followers }\end{array}$ & $\begin{array}{l}\text { Profile } \\
\text { visits }\end{array}$ & Impressions \\
\hline $\begin{array}{l}\text { Baseline } \\
\text { (Aug 1- } \\
\text { Sept 30, } \\
2019 \text { ) } \\
\end{array}$ & $\begin{array}{c}19.5 \\
(16.3)\end{array}$ & $\begin{array}{c}223.0 \\
(127.3)\end{array}$ & $\begin{array}{l}21850.0 \\
(5161.9)\end{array}$ & $\begin{array}{c}26.5 \\
(12.0)\end{array}$ & $\begin{array}{l}197.5 \\
(77.1)\end{array}$ & $\begin{array}{l}41200.0 \\
(9192.4)\end{array}$ & $\begin{array}{c}6.0 \\
(8.5)\end{array}$ & $\begin{array}{l}106.0 \\
(9.9)\end{array}$ & $\begin{array}{c}2432.5 \\
(1672.3)\end{array}$ \\
\hline $\begin{array}{l}\text { Campaign } \\
\text { (October } 14 \\
\text { - Nov 30, } \\
2019 \text { ) } \\
\end{array}$ & $\begin{array}{l}24.5 \\
(6.4)\end{array}$ & $\begin{array}{c}621.5 \\
(443.4)\end{array}$ & $\begin{array}{c}40950.0 \\
(20718.2)\end{array}$ & $\begin{array}{l}41.0 \\
(8.5)\end{array}$ & $\begin{array}{l}309.5 \\
(4.9)\end{array}$ & $\begin{array}{c}54150.0 \\
(777.8)\end{array}$ & $\begin{array}{c}8.5 \\
(2.1)\end{array}$ & $\begin{array}{l}208.5 \\
(54.4)\end{array}$ & $\begin{array}{c}7857.5 \\
(3312.8)\end{array}$ \\
\hline $\begin{array}{l}\text { Post- } \\
\text { campaign } \\
\text { (Dec } 1 \text {, } \\
2019- \\
\text { March } 31 \text {, } \\
\text { 2020) } \\
\end{array}$ & $\begin{array}{l}19.8 \\
(7.3)\end{array}$ & $\begin{array}{l}238.8 \\
(30.5)\end{array}$ & $\begin{array}{l}25675.0 \\
(6903.3)\end{array}$ & $\begin{array}{c}29.5 \\
(13.3)\end{array}$ & $\begin{array}{l}174.0 \\
(29.8)\end{array}$ & $\begin{array}{l}28250.0 \\
(6119.1)\end{array}$ & $\begin{array}{c}7.5 \\
(1.9)\end{array}$ & $\begin{array}{c}96.5 \\
(69.6)\end{array}$ & $\begin{array}{c}6112.0 \\
(2031.7)\end{array}$ \\
\hline $\begin{array}{l}\text { Change } \\
\text { from } \\
\text { baseline to } \\
\text { campaign, } \\
\mathrm{N}(\%)\end{array}$ & $\begin{array}{c}5.0 \\
(25.6)\end{array}$ & $\begin{array}{c}398.5 \\
(178.7)\end{array}$ & $\begin{array}{l}19100.0 \\
(87.4)\end{array}$ & $\begin{array}{c}14.5 \\
(54.7)\end{array}$ & $\begin{array}{l}112.0 \\
(56.7)\end{array}$ & $\begin{array}{c}12950.0 \\
(31.4)\end{array}$ & $\begin{array}{c}2.5 \\
(41.7)\end{array}$ & $\begin{array}{l}102.5 \\
(96.7)\end{array}$ & $\begin{array}{l}5425.0 \\
(223.0)\end{array}$ \\
\hline $\begin{array}{l}\text { Change } \\
\text { from } \\
\text { campaign } \\
\text { to post- } \\
\text { campaign, } \\
\mathrm{N}(\%) \\
\end{array}$ & $\begin{array}{c}-4.7 \\
(-19.4)\end{array}$ & $\begin{array}{l}-382.7 \\
(-61.6)\end{array}$ & $\begin{array}{c}-15275.0 \\
(-37.3)\end{array}$ & $\begin{array}{c}-11.5 \\
(-28.0)\end{array}$ & $\begin{array}{l}-135.5 \\
(-43.8)\end{array}$ & $\begin{array}{c}-25900.0 \\
(-47.8)\end{array}$ & $\begin{array}{c}-1.0 \\
(-11.8)\end{array}$ & $\begin{array}{l}-112.0 \\
(-53.7)\end{array}$ & $\begin{array}{c}-1745.5 \\
(-22.2)\end{array}$ \\
\hline
\end{tabular}

campaign, the ECHO Twitter followers increased on average by 24.5 followers per month $(25.6 \%$ increase). After the campaign, the average number of new followers per month was 19.8 , which represents a $19.4 \%$ decrease compared to the campaign period. The ECHO Twitter account had a baseline of 223 average monthly profile visits and 21850 average monthly impressions. During the campaign, the average monthly profile visits increased to 621.5 (178.7\% increase) and monthly mean impressions increased to 40950 (87.4\% increase). Following the campaign, mean profile visits decreased to 238.8 per month (61.6\% decrease compared to campaign averages) and monthly mean impressions decreased to 25675 (37.3\% decrease compared to campaign averages). Figure 2 displays the monthly metrics collected for the ECHO Twitter account.

\section{@arche4evidence}

The ARCHE Twitter account had an average of 6 new followers per month at baseline. During the campaign, followers increased on average by 8.5 followers per month (41.7\% increase). Following the campaign, the mean number of new followers was 7.5 per month $(11.8 \%$ decrease compared to during campaign averages). As well, the ARCHE Twitter had 106 monthly profile visits and 2432.5 impressions per month at baseline. Throughout the campaign, mean profile visits increased to 208.5 visits per month (96.7\% increase) and monthly mean impressions became 7857.5 impressions per month (223\% increase). After the campaign, monthly average profile visits dropped to 96.5 (53.7\% decrease) and monthly mean impressions became 6112 (22.2\% decrease) compared to the during campaign averages. Figure 3 depicts the monthly trends of the ARCHE Twitter's metrics.

\section{@TREKKca}

The TREKK Twitter account had an average baseline of 26.5 new followers per month. Throughout the post-campaign period, the monthly mean profile visits decreased to 174 (43.8\% decrease compared to campaign averages) and the average impressions fell to 28250 (47.8\% decrease compared to campaign averages). The monthly metrics of the TREKK Twitter 
are displayed in Figure 4.

\section{Interactions with Facebook Accounts}

Table 3 shows average monthly user interactions with ECHO and TREKK Facebook accounts.

\section{@echoKTresearch}

At baseline, the ECHO Facebook account had a monthly mean of 2.5 page likes. During the campaign the mean monthly page likes remained 2.5 likes ( $0 \%$ increase) and mean monthly page likes decreased to 2.3 likes per month (1.2\% decrease compared to the during campaign averages) after the campaign. The ECHO Facebook had a mean baseline post reach of 76.2 per month. In the campaign period, the mean monthly post reach was 123.5 per month $(62.1 \%$ increase). In the post-campaign period, the mean monthly post reach became 122 per month, indicating a $1.2 \%$ decrease from the campaign average. Figure

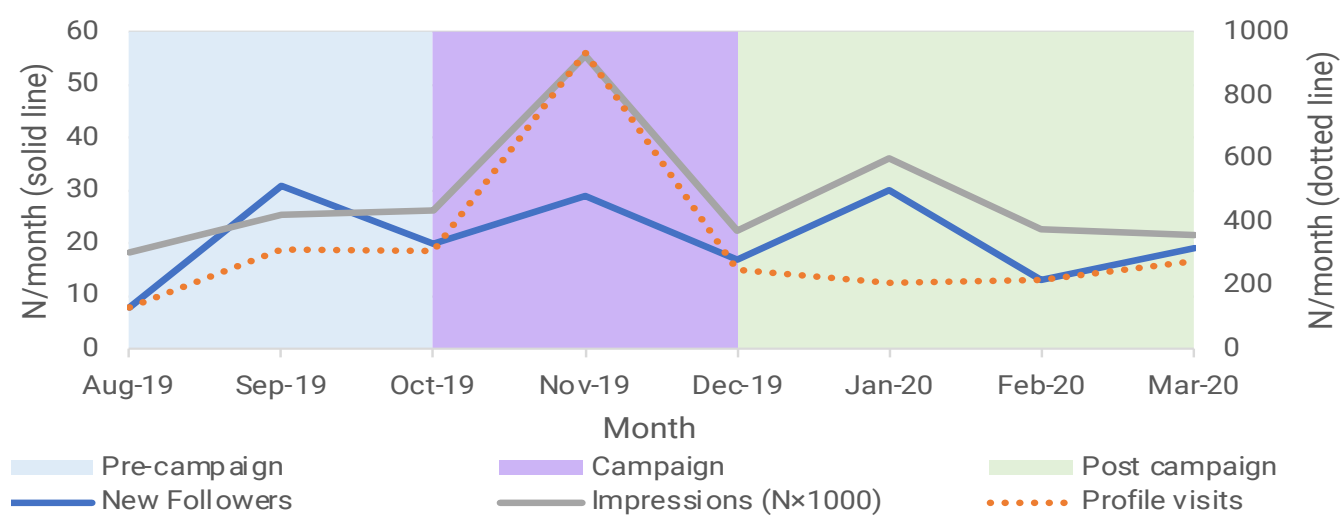

Figure 2: Monthly user interactions with @echoKTresearch Twitter

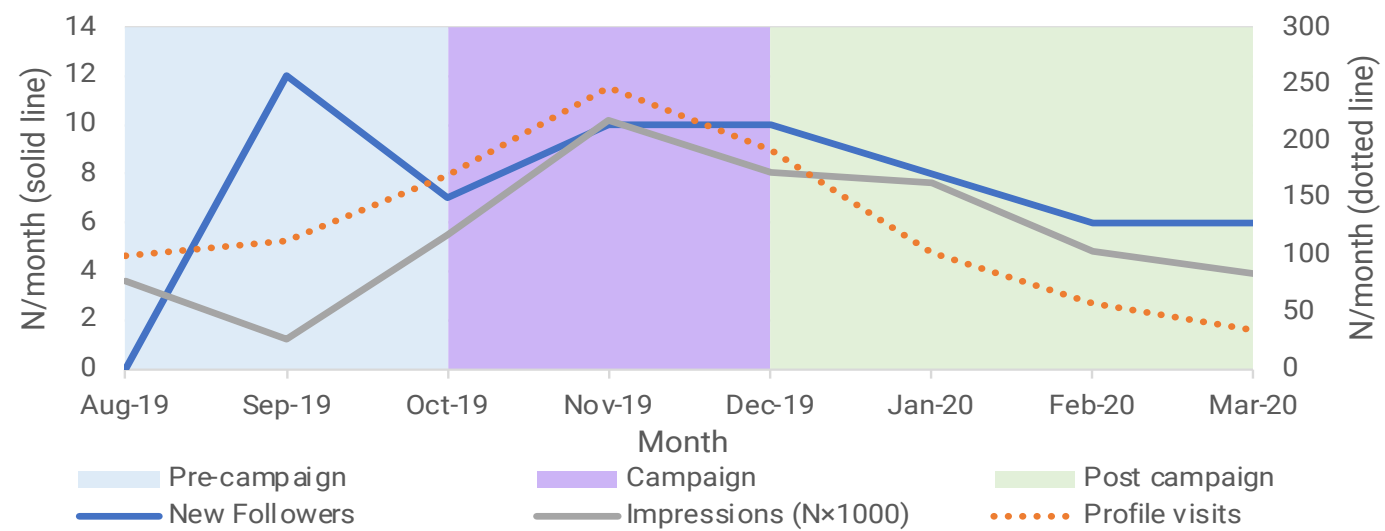

Figure 3: Monthly user interactions with @Arche4evidence Twitter

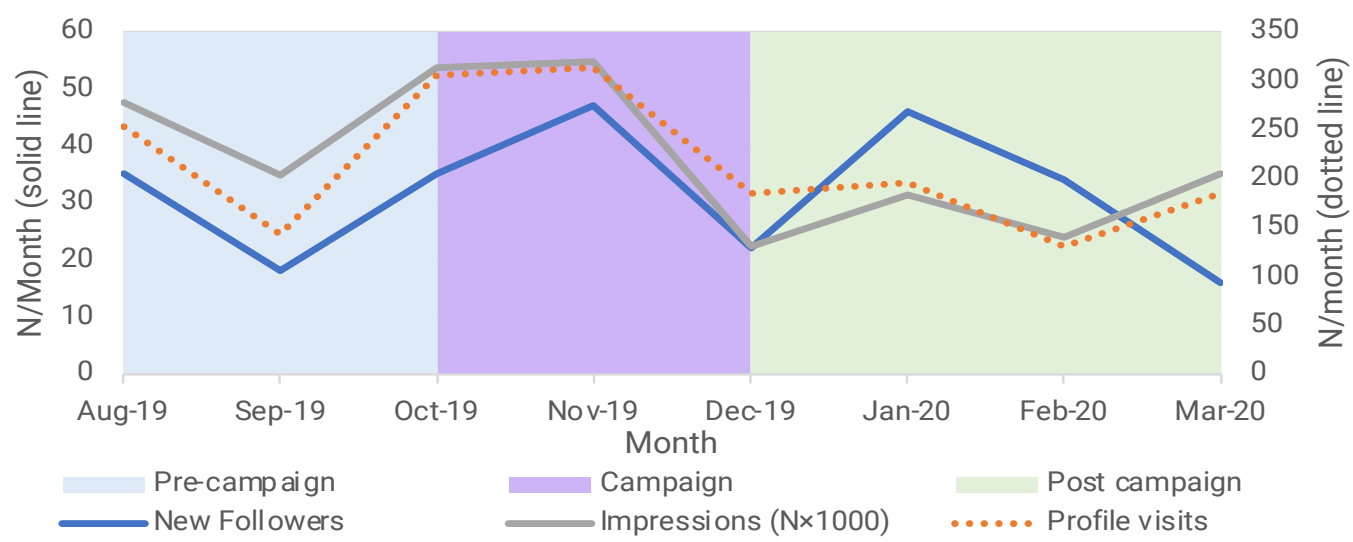

Figure 4: Monthly user interactions with @TREKKca Twitter 
Table 3: Average user interactions with Facebook accounts per month

\begin{tabular}{|c|c|c|c|c|}
\hline Social & ECHO Fac & Mean (SD) & TREKK Fac & , Mean (SD) \\
\hline $\begin{array}{l}\text { Periods } \\
\text { compared }\end{array}$ & Page Likes & $\begin{array}{l}\text { Monthly Post } \\
\text { Reach }\end{array}$ & Page Likes & $\begin{array}{l}\text { Monthly Post } \\
\text { Reach }\end{array}$ \\
\hline $\begin{array}{l}\text { Baseline (Aug } 1 \\
\text {-Sept 30, 2019) }\end{array}$ & $\begin{array}{c}2.5 \\
(2.1)\end{array}$ & $\begin{array}{c}76.2 \\
(36.5)\end{array}$ & $\begin{array}{c}5.5 \\
(2.1)\end{array}$ & $\begin{array}{l}107.0 \\
(55.2)\end{array}$ \\
\hline $\begin{array}{l}\text { Campaign } \\
\text { (October } 14- \\
\text { Nov 30, 2019) }\end{array}$ & $\begin{array}{c}2.5 \\
(3.5)\end{array}$ & $\begin{array}{l}123.5 \\
(64.3)\end{array}$ & $\begin{array}{l}17.0 \\
(1.4)\end{array}$ & $\begin{array}{l}172.5 \\
(81.3)\end{array}$ \\
\hline $\begin{array}{l}\text { Post-campaign } \\
\text { (Dec 1, 2019 - } \\
\text { March 31, 2020) }\end{array}$ & $\begin{array}{c}2.3 \\
(3.5)\end{array}$ & $\begin{array}{c}122.0 \\
(136.3)\end{array}$ & $\begin{array}{l}15.3 \\
(3.8)\end{array}$ & $\begin{array}{l}209.3 \\
(60.4)\end{array}$ \\
\hline $\begin{array}{l}\text { Change from } \\
\text { baseline to } \\
\text { campaign, } \\
\mathrm{N}(\%)\end{array}$ & $\begin{array}{c}0.0 \\
(0.0)\end{array}$ & $\begin{array}{c}47.3 \\
(62.1)\end{array}$ & $\begin{array}{c}11.5 \\
(209.1)\end{array}$ & $\begin{array}{c}65.5 \\
(61.2)\end{array}$ \\
\hline $\begin{array}{l}\text { Change from } \\
\text { campaign to } \\
\text { post-campaign, } \\
\mathrm{N}(\%)\end{array}$ & $\begin{array}{l}-0.2 \\
(-6.7)\end{array}$ & $\begin{array}{l}-1.5 \\
(-1.2)\end{array}$ & $\begin{array}{l}-1.7 \\
(-9.8)\end{array}$ & $\begin{array}{c}36.8 \\
(21.3)\end{array}$ \\
\hline
\end{tabular}

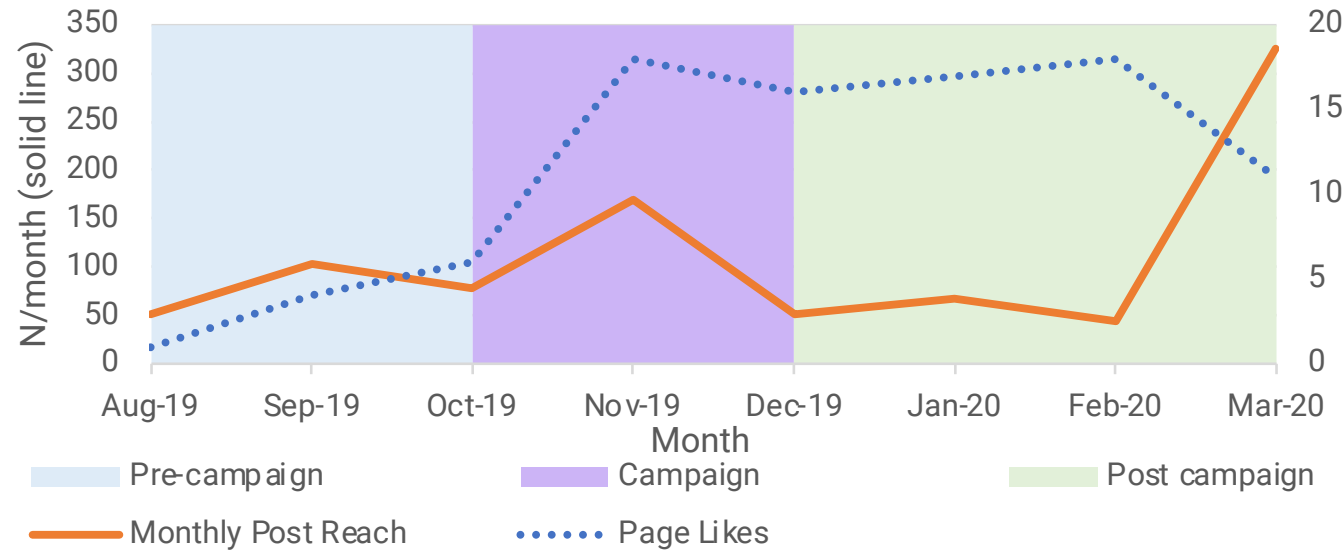

Figure 5: Monthly user interactions with @echoKTresearch Facebook

5 shows the ECHO Facebook's metrics.

\section{@TREKKca}

The TREKK Facebook account had an average baseline of 5.5 page likes per month. This increased to 17 likes per month (209.1\% increase) during the campaign. Following the campaign, the average monthly page likes dropped to 15.3 likes, signalling a $9.8 \%$ decrease from the campaign average. The TREKK Facebook account also had an average monthly post reach baseline of 107 . Throughout the campaign, this increased to 172.5 per month $(61.2 \%$ increase compared to campaign averages). Following the campaign, average monthly post reach increased to 209.3 (21.3\% increase compared to campaign averages). Monthly metrics for the TREKK Twitter are displayed in Figure 6 below.

Interactions with Websites

Table 4 shows average monthly user interactions with ECHO and TREKK Websites. 


\section{ECHO Website}

The ECHO website had an average of 2709.5 visits per month at baseline, with 283 visits to the 'Tools' page. No average baseline was recorded for Bit. ly click counts for the 'Tools' page as the link was created at the beginning of the campaign. Throughout the campaign, the average monthly website visits decreased to 2633.5 (2.8\% decrease) while the average monthly views of the 'Tools' page increased to 1541 ( $444.5 \%$ increase). The bit.ly link for the 'Tools' page had a monthly average of 815.5 clicks during the campaign. Following the campaign, monthly mean website visits decreased to 1891.5 visits $(28.2 \%$ decrease compared to campaign averages) and the 'Tools' page visits decreased to 459.0 (70.2\% decrease compared to campaign averages). The Bit.ly click count for the 'Tools' page post-campaign dropped to 117.8 per month, representing an $85.6 \%$ decrease

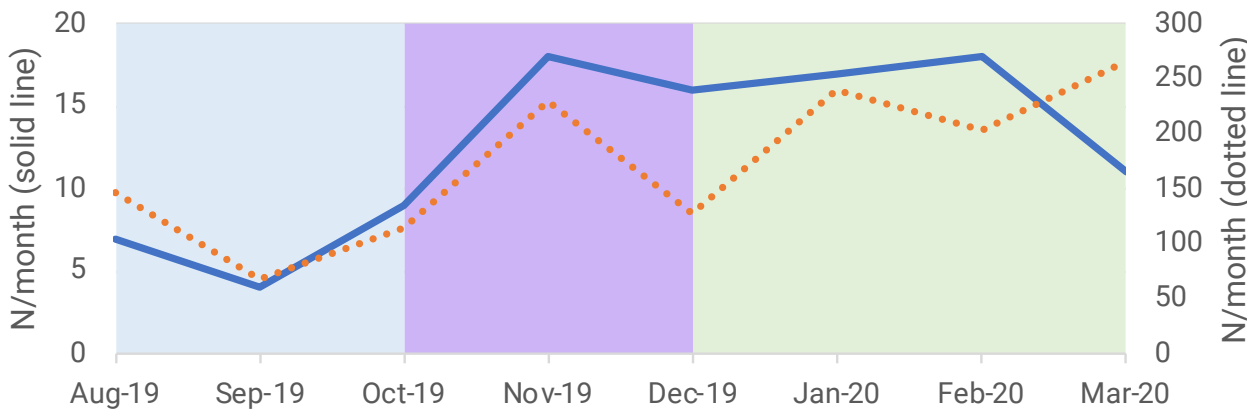

Month

Pre-campaign

Campaign

Post campaign

Page Likes

..... Monthly Post Reach

Figure 6: Monthly user interactions with @TREKKca Facebook

Table 4: Average user interactions with ECHO and TREKK websites per month

\begin{tabular}{|c|c|c|c|c|c|c|}
\hline \multirow[b]{2}{*}{$\begin{array}{l}\text { Social } \\
\text { media }\end{array}$} & \multicolumn{3}{|c|}{ ECHO Website, Mean (SD) } & \multicolumn{3}{|c|}{ TREKK Website, Mean (SD) } \\
\hline & $\begin{array}{c}\text { Website } \\
\text { visits }\end{array}$ & $\begin{array}{c}\text { Website } \\
\text { visits to } \\
\text { 'Tools' } \\
\text { page }\end{array}$ & $\begin{array}{l}\text { Bit.ly click } \\
\text { count for } \\
\text { tools page }\end{array}$ & $\begin{array}{c}\text { Website } \\
\text { visits }\end{array}$ & $\begin{array}{c}\text { Website visits } \\
\text { to } \\
\text { 'Parent/Family' } \\
\text { page }\end{array}$ & $\begin{array}{l}\text { Bit.ly click } \\
\text { count for } \\
\text { tools page }\end{array}$ \\
\hline $\begin{array}{l}\text { Baseline (Aug } \\
\text { 1- Sept 30, } \\
\text { 2019) }\end{array}$ & $\begin{array}{l}2709.5 \\
(388.2)\end{array}$ & $\begin{array}{l}283.0 \\
(55.2)\end{array}$ & & $\begin{array}{l}3626.0 \\
(589.0)\end{array}$ & $\begin{array}{l}267.0 \\
(25.5)\end{array}$ & \\
\hline $\begin{array}{l}\text { Campaign } \\
\text { (October } 14- \\
\text { Nov 30, 2019) }\end{array}$ & $\begin{array}{l}2633.5 \\
(183.1)\end{array}$ & $\begin{array}{l}1541.0 \\
(175.4)\end{array}$ & $\begin{array}{c}815.5 \\
(572.0)\end{array}$ & $\begin{array}{l}5270.5 \\
(334.5)\end{array}$ & $\begin{array}{c}346.5 \\
(153.4)\end{array}$ & $\begin{array}{l}28.5 \\
(14.8)\end{array}$ \\
\hline $\begin{array}{l}\text { Post-campaign } \\
\text { (Dec 1, 2019 - } \\
\text { March 31, } \\
\text { 2020) }\end{array}$ & $\begin{array}{l}1891.5 \\
(122.5)\end{array}$ & $\begin{array}{c}459.0 \\
(127.3)\end{array}$ & $\begin{array}{l}117.8 \\
(41.9)\end{array}$ & $\begin{array}{c}4548.8 \\
(1049.1)\end{array}$ & $\begin{array}{l}235.8 \\
(47.9)\end{array}$ & $\begin{array}{c}32.8 \\
(37.5)\end{array}$ \\
\hline $\begin{array}{l}\text { Change from } \\
\text { baseline to } \\
\text { campaign, } \\
\mathrm{N}(\%)\end{array}$ & $\begin{array}{l}-76.0 \\
(-2.8)\end{array}$ & $\begin{array}{l}1258.0 \\
(444.5)\end{array}$ & & $\begin{array}{c}1644.5 \\
(45.4)\end{array}$ & $\begin{array}{c}79.5 \\
(29.8)\end{array}$ & \\
\hline $\begin{array}{l}\text { Change from } \\
\text { campaign to } \\
\text { post- } \\
\text { campaign, } \mathrm{N} \\
(\%)\end{array}$ & $\begin{array}{l}-742.0 \\
(-28.2)\end{array}$ & $\begin{array}{c}-1082.0 \\
(-70.2)\end{array}$ & $\begin{array}{l}-697.7 \\
(-85.6)\end{array}$ & $\begin{array}{l}-721.7 \\
(-13.7)\end{array}$ & $\begin{array}{l}-110.7 \\
(-32.0)\end{array}$ & $\begin{array}{c}4.3 \\
(14.9)\end{array}$ \\
\hline
\end{tabular}


compared to during campaign averages. Figure 7 displays monthly user interactions collected for the ECHO website.

\section{TREKK Website}

At baseline, the TREKK website received an average of 3626 visits per month, including an average of 267 visits per month on the 'Parent/Family' page. No baseline click count for the Bit.ly link was recorded as the link was made at the start of the campaign. During the campaign, monthly average website visits increased to 5270.5 (45.4\% increase) and average monthly visits to the 'Parent/Family' page increased to 346.5 (29.8\% increase). A monthly average of 28.5 clicks were recorded for the Bit.ly 'Parent/Family' page link. During the post-campaign period, mean monthly website visits decreased to 4548.8 (13.7\% decrease) and monthly mean visits to the 'Parent/ Family' page decreased to 235.8 (32\% decrease).
The Bit.ly link for the tools page increased to 32.8 (14.9\% increase) monthly mean clicks post-campaign. The TREKK website's monthly metrics are shown in Figure 8.

\section{Interactions with YouTube}

As the bronchiolitis video was uploaded to YouTube in November 2019, no baseline data was recorded. As shown in Table 5, the video had 5273 views during the month of November. The number of monthly views decreased to 80 views following the campaign (98.5\% decrease from campaign average). The video recorded an average watch time of 4.9 hours per month and an average view duration of 1.63 minutes per month during the campaign. Following the campaign, the average watch time decreased to 0.08 hours per month (98.3\% decrease from campaign), but the video was viewed for longer as demonstrated by view duration increasing to 1.65 minutes per month (1\% increase

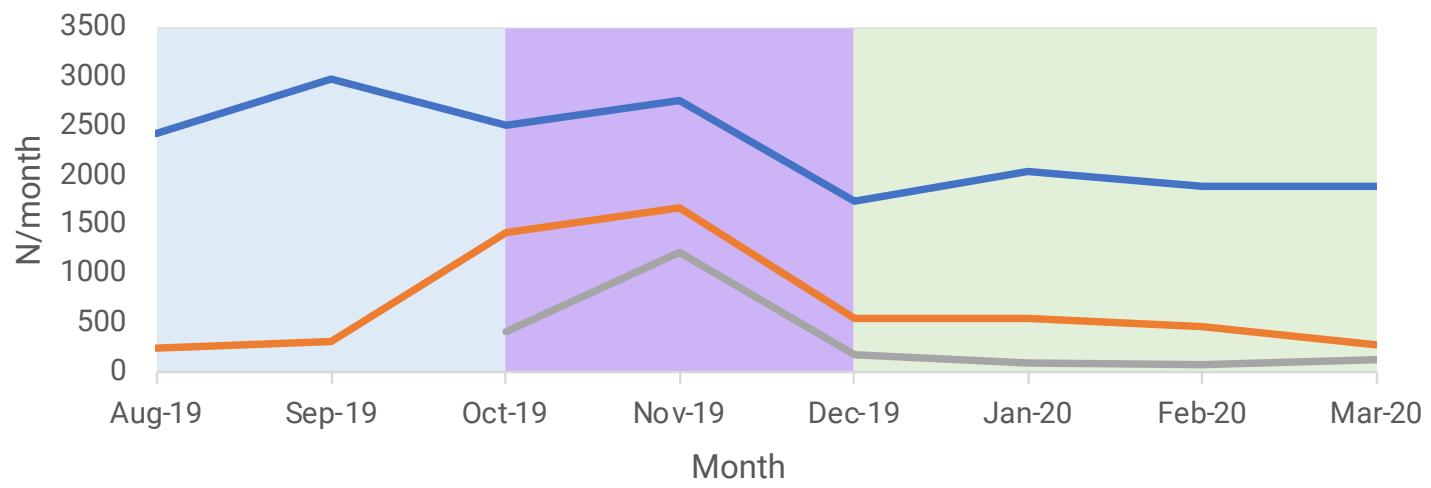

Pre-campaign

Campaign

Post campaign Website visits

Figure 7: Monthly interactions with ECHO website

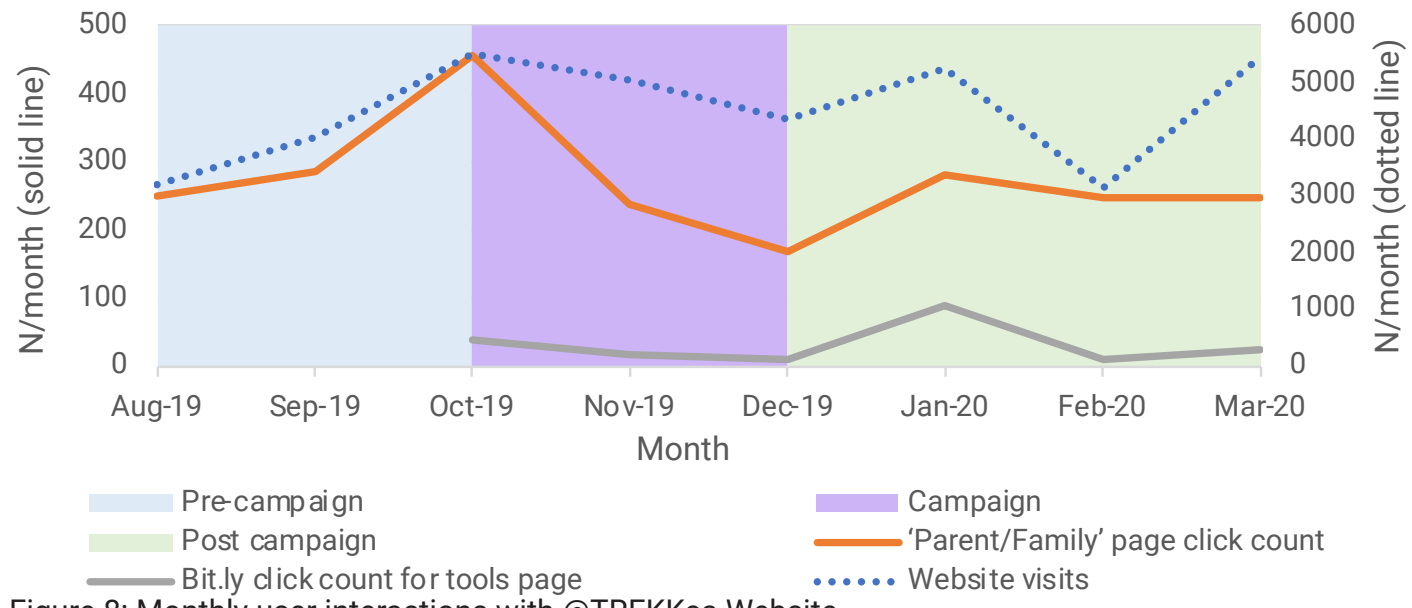

Figure 8: Monthly user interactions with @TREKKca Website 
Table 5: Average Interactions with Bronchiolitis YouTube Video

\begin{tabular}{|l|c|c|c|c|}
\hline $\begin{array}{l}\text { Periods } \\
\text { compared }\end{array}$ & Views & Watch time (hours) & $\begin{array}{c}\text { View duration } \\
\text { (minutes) }\end{array}$ & Impressions \\
\hline $\begin{array}{l}\text { Campaign (Nov 1 - } \\
\text { Nov 30, 2019) }\end{array}$ & 5273 & 4.9 & 1.63 & 236.3 \\
\hline $\begin{array}{l}\text { Post-campaign (Dec } \\
1,2019-\end{array}$ & 80 & 0.08 & 1.65 & 60.2 \\
Mar 31, 2020) & -5193 & $\begin{array}{c}-4.8 \\
(-98.3)\end{array}$ & 0.02 & -176.1 \\
\hline $\begin{array}{l}\text { Change from } \\
\text { campaign to post- } \\
\text { campaign, N (\%) }\end{array}$ & $(-98.5)$ & $(1.0)$ & $(-74.5)$ \\
\hline
\end{tabular}

from campaign). During the campaign the video had an average of 236.3 impressions. This decreased to 60.2 impressions (74.5\% decrease from campaign) following the campaign.

\section{Discussion}

Through this study we hoped to evaluate the effectiveness of a social media campaign used to disseminate a bronchiolitis video. The goals of this campaign were to (1) increase the bronchiolitis video's reach and views, (2) increase website interactions with the KT tools section, and (3) engage the caregivers within $\mathrm{ECHO}, \mathrm{ARCHE}$, and TREKK networks.

An increase in metrics above baseline averages were noted during the social media campaign. We also noted a decrease in user interaction following the event. There could be many explanations for these changes as metrics on social media platforms can be affected by multiple factors other than posts. Accounts were active throughout the campaign, so it is impossible to directly attribute increase in user interactions to the social media campaign. As well, in-person promotions may have impacted user interactions with social media accounts and the bronchiolitis video. Some additional potential factors may include follower interests, and season or time of year as bronchiolitis is most common in late fall and winter (Bloom-Feshbach et al., 2013).

Healthcare is a complex field in which clinicians are required to integrate research into practice to provide the highest quality of care (Munro \& Hope, 2019; Stevens, 2013). Yet, it has been found that $30-40 \%$ of patients are estimated to not receive evidence-based care (Grol \& Grimshaw, 2003) and $86 \%$ of relevant research evidence is not implemented into clinical practice (Scott. et al., 2013). Common barriers for translating research to practice are lack of knowledge of available resources, lack of funding, lack of support from management, organisational culture, and time constraints (Curtis et al., 2018; Man et al., 2018). The wide reach of social media and potential for discussion makes social media a costeffective option to disseminate and uptake knowledge for HCPs, patients, and families alike (Tunnecliff et al., 2015; Unnikrishnan et al., 2018). The data generated from this campaign shows that social media may be a useful resource for research dissemination by increasing traffic towards our tools. This may allow for more patients, families, and HCPs to easily access and use our tools.

Although social media may provide a wide array of useful information to patients, families, and HCPs, the information is usually unregulated and has varying levels of credibility (Ghaisani et al., 2017; Huo et al., 2018; Tunnecliff et al., 2015). The amount of information available on social media is also growing, making the task of evaluating reliability difficult for users (Borah \& Xiao, 2018). Many factors impact perception of credibility for the audience. Such factors include expertise and credibility of sources; message, platform, and additional links; and videos, audio clips, and personal stories for further information 
(Borah \& Xiao, 2018; Ghaisani et al., 2017; Majid et al., 2019). The large amount of information available creates a challenge for users to choose the most applicable approach (Viviani \& Pasi, 2017). Therefore, these challenges demonstrate the need of further investigating methods to identify reliable information and means of effectively disseminating such information.

\section{Limitations}

There were some limitations to our social media dissemination promotion. Because our research expertise does not lie in media communications, we may have overlooked alternative ways to measure performance during the campaign. For example, we could have tracked follower demographics or we could have created posts that catered to various interests. These methods may have provided a better demonstration of the campaign's dissemination potential. Many organizations also do not have specialized personnel managing social media profile leading to variations in data collection and recording methods. This suggests the need for standardized guides on conduction of effective and efficient social media campaigns. As well, the period of times for the pre-campaign, campaign, and post-campaign were not equal. This may have impacted comparisons because the periods with shorter times may have had a higher chance of being skewed as there is less data collected.

Implications for Research and Practice

During the campaign, there was an overall increase in metrics; however, metric increases varied. For example, during the campaign, the TREKK Twitter's impressions increased by $31.4 \%$ while the ARCHE Twitter's impressions increased by $223.0 \%$ from baseline. This suggests that some posts were better received, and different accounts generated higher user interactions. We cannot identify a pattern to determine most popular or effective post styles as there were multiple posts per week in differing formats. It is difficult to identify a pattern in posts that generated the highest user interaction across accounts as various accounts may have drawn different demographics of users. Post-campaign, there was a downward trend in the data, indicating reduced user interactions and reach of tools following a campaign. To our knowledge, limited research has been conducted to determine the most effective formats for disseminating health care information on social media and the best formats to generate continuous user interactions. Research in other contexts, such as marketing and private healthcare, indicate posts which provide private insight generate the highest interaction rate as users become emotionally involved (Klietz et al., 2019). The varying amounts of metrics increases, and limited research suggests a need to explore factors which contribute to posts that increase and maintain user interests for different demographics. In future studies, it would be beneficial to track specific posts and utilize various formats targeting different demographics and interests to explore which post designs are most effective in increasing and maintaining user interactions.

\section{Conclusion}

There was a visible increase in overall followers, likes, post reach, impressions, profile visits, and website clicks for all accounts during the campaign period. This suggests social media is a useful method of dissemination as it has the potential to reach large audiences. In-person promotions and additional activity of social media accounts may have also impacted user interactions. It is still unclear how to best structure social media posts for dissemination and how to distinguish credibility. In addition, there is a downward trend in metrics during the postcampaign period, suggesting the importance of further investigating methods to maintain continuous interaction with accounts following a campaign. It is therefore important to continue evaluating and measuring social media campaigns. Results of such studies may inform best practices when designing future social media campaigns to ensure the tools being disseminated may reach the largest audience possible. 


\section{Acknowledgements}

We would like to thank the organizations that funded research team members. HS received studentship funding from the Women and Children's Health Research Institute and the Faculty of Nursing. LH and SS hold a Canada Research Chair and are Distinguished Researchers in the Stollery Science Lab program. TREKK and Networks of Centres of Excellence provided personnel funding for SS. We wish to thank IHDCYH. Lastly, we would like to thank everyone involved with collecting social media data. 


\section{References}

ARCHE [@arche4evidence]. (n.d.). Tweets [Twitter profile]. Twitter. Retrieved December 6, 2021, from https://twitter.com/arche4evidence?ref_

Bjornson, C. L., Klassen, T. P., Williamson, J., Brant, R., Mitton, C., Plint, A., Bulloch, B., Evered, L., \& Johnson, D. W., Pediatric Emergency Research Canada Network (2004). A randomized trial of a single dose of oral dexamethasone for mild croup. The New England Journal of Medicine, 351(13), 1306-1313. https://doi.org/10.1056/NEJMoa033534

Bloom-Feshbach, K., Alonso, W. J., Charu, V., Tamerius, J., Simonsen, L., Miller, M. A., \& Viboud, C. (2013). Latitudinal variations in seasonal activity of influenza and respiratory syncytial virus (RSV): a global comparative review. PLOS One, 8(2), e54445.

https://doi.org/10.1371/journal.pone.0054445

Borah, P., \& Xiao, X. (2018). The importance of 'likes': The interplay of message framing, source, and social endorsement on credibility perceptions of health information on Facebook. Journal of Health Communication, 23(4), 399-411. https://doi.org/10.1080/10810730.2018.1455770

Cabral, C., Ingram, J., Hay, A. D., \& Horwood, J. (2014). "They just say everything's a virus"-Parents judgment of the credibility of clinician communication in primary care consultations for respiratory tract infections in children: A qualitative study. Patient Education and Counseling, 95(2), 248-253. https://doi.org/10.1016/j.pec.2014.01.010

Campbell, A., Hartling, L., Louie-Poon, S., \& Scott, S. D. (2019). Parents' information needs and preferences related to bronchiolitis: A qualitative study. CMAJ Open, 7(4), E640-E645. https://doi.org/10.9778/cmajo.20190092

Canadian Institutes of Health Research. (2021, November 19). Institute of Human Development, Child and Youth Health. https://cihr-irsc.gc.ca/e/8688.html

Chin, R., Browne, G. J., Lam, L. T., McCaskill, M. E., Fasher, B., \& Hort, J. (2002). Effectiveness of a croup clinical pathway in the management of children with croup presenting to an emergency department. Journal of Paediatrics and Child Health, 38(4), 382-387. https://doi.org/10.1046/i.1440-1754.2002.00011.x

Coffin, S. E. (2005). Bronchiolitis: In-patient focus. Pediatric Clinics of North America, 52(4), 1047-1057. https://doi.org/10.1016/j.pcl.2005.04.002

Curtis, K., Fulton, E., \& Brown, K. (2018). Factors influencing application of behavioural science evidence by public health decision-makers and practitioners, and implications for practice. Preventive Medicine Reports, 12, 106-115. https://doi.org/10.1016/j.pmedr.2018.08.012

ECHO Research. (n.d.). Home [Facebook page]. Facebook. Retrieved December 6, 2021, from https://www.facebook.com/echoKTresearch/

ECHO Research. (2019, November 20). Bronchiolitis is a viral infection commonly caused by RSV (respiratory syncytial virus). Common symptoms include: fever, runny nose/cough, wheezing [image attached] [Post]. Facebook.

https://www.facebook.com/echoKTresearch/posts/2634180493305690?__cft__[0]=AZWTmJ vNV2rggMmwW6non0boQDNHFBli30r7qp28ghMZJCTIdrbPeDzIUe5RVHDTzq9wJXrySxstAMO PIdxWKuyQp3rsJyfOUznANfB-owCqLuR-XVUTEV_2JdiyUx_luzrZDXczQm9j4DhoeRav9MJx\&__ tn__ $=\% 2 \mathrm{CO} \% 2 \mathrm{CP}-\mathrm{R}$

ECHO Research. (2020a). Home. https://www.echokt.ca/

ECHO Research. (2020b). Tools. https://www.echokt.ca/tools/

Florin, T. A., Byczkowski, T., Ruddy, R. M., Zorc, J. J., Test, M., \& Shah, S. S. (2014). Variation in the 
management of infants hospitalized for bronchiolitis persists after the 2006 American Academy of Pediatrics bronchiolitis guidelines. The Journal of Pediatrics, 165(4), 786-792.

https://doi.org/10.1016/j.jpeds.2014.05.057

Gates, M., Shulhan-Kilroy, J., Featherstone, R., Macgregor, T., Scott, S.D, \& Hartling, L. (2019). Parent experiences and information needs related to bronchiolitis: A mixed studies systematic review. Patient Education and Counseling, 102(5), 864-878. https://doi.org/10.1016/j.pec.2018.12.013

Ghaisani, A. P., Munajat, Q., \& Handayani, P. W. (2017). Information credibility factors on information sharing activities in social media. 2017 Second International Conference on Informatics and Computing (ICIC), 1-5. https://doi.org/10.1109/iac.2017.8280655

Graham, I. D., \& Tetroe, J. (2007). How to translate health research knowledge into effective healthcare action. Healthcare Quarterly, 10(3), 20-22. https://doi.org/10.12927/hcq..18919

Grol, R., \& Grimshaw, J. (2003). From best evidence to best practice: Effective implementation of change in patients' care. The Lancet, 362(9391), 1225-1230. https://doi.org/10.1016/S0140-6736(03)14546-1

Gruzd, A., Jacobson J., Mai P., \& Dubois E. (2018). The State of Social Media in Canada 2017 (Version1). Ryerson University. https://doi.org/10.32920/14636136.v1

Huo, C., Zhang, M., \& Ma, F. (2018). Factors influencing people's health knowledge adoption in social media. Library Hi Tech, 36(1), 129-151. https://doi.org/10.1108/lht-04-2017-0074

IHDCYH Talks. (2019, November 1). Specially commended, 2019: Cough, cold and wheeze: How to help manage your child's bronchiolitis [Video]. YouTube.

https://www.youtube.com/watch?v=jMO_QIMzlqU\&ab_ channel=IHDCYHTalks\%7CEntretiensdel\%27IDSEA

Kamban, S. W., \& Svavarsdottir, E. K. (2013). Does a therapeutic conversation intervention in an acute paediatric setting make a difference for families of children with bronchiolitis caused by respiratory syncytial virus (RSV)? Journal of Clinical Nursing, 22(19-20), 2723-2733. https://doi.org/10.1111/j.1365-2702.2012.04330.x

Kaushal, R., Bates, D. W., Landrigan, C., McKenna, K. J., Clapp, M. D., Federico, F., \& Goldmann, D. A. (2001). Medication errors and adverse drug events in pediatric inpatients. JAMA, 285(16), 21142120. https://doi.org/10.1001/jama.285.16.2114

Klietz, M., Kaiser, H. W., Machens, H., \& Aitzetmüller, M. M. (2019). Social media marketing: What do prospective patients want to see? Aesthetic Surgery Journal, 40(5), 577-583. https://doi.org/10.1093/asj/sjz204

Langley, J. M., Wang, E. E., Law, B. J., Stephens, D., Boucher, F. D., Dobson, S., McDonald, J., MacDonald, N. E., Mitchell, I., \& Robinson, J. L. (1997). Economic evaluation of respiratory syncytial virus infection in Canadian children: A Pediatric Investigators Collaborative Network on Infections in Canada (PICNIC) study. The Journal of Pediatrics, 131(1), 113-117. https://doi.org/10.1016/s0022-3476(97)70133-1

Leidy, N. K., Margolis, M. K., Marcin, J. P., Flynn, J. A., Frankel, L. R., Johnson, S., Langkamp, D., \& Simoes, E. A. F. (2005). The impact of severe respiratory syncytial virus on the child, caregiver, and family during hospitalization and recovery. American Academy of Pediatrics. 115(6), 1536-1546. https://pediatrics.aappublications.org/content/115/6/1536

Majid, S., Lopez, C., Megicks, P., \& Lim, W. M. (2019). Developing effective social media messages: Insights from an exploratory study of industry experts. Psychology \& Marketing, 36(6), 551-564. https://doi.org/10.1002/mar.21196 
Man, J., Kangas, M., Trollor, J., \& Sweller, N. (2018). Clinical practices and barriers to best practice implementation of psychologists working with adults with intellectual disability and comorbid mental ill health. Journal of Policy and Practice in Intellectual Disabilities, 15(3), 256-266. https://doi.org/10.1111/jppi.12256

Miller, E. K., Gebretsadik, T., Carroll, K. N., Dupont, W. D., Mohamed, Y. A., Morin, L. L., Heil, L., Minton, P. A., Woodward, K., Liu, Z., Hartert, T. V., \& Williams, J. V. (2013). Viral etiologies of infant bronchiolitis, croup and upper respiratory illness during 4 consecutive years. The Pediatric Infectious Disease Journal, 32(9), 950-955. https://doi.org/10.1097/INF.0b013e31829b7e43

Moorhead, S. A., Hazlett, D. E., Harrison, L., Carroll, J. K., Irwin, A., \& Hoving, C. (2013). A new dimension of health care: Systematic review of the uses, benefits, and limitations of social media for health communication. Journal of Medical Internet Research, 15(4), e85.

https://doi.org/10.2196/jmir.1933

Munro, C. L., \& Hope, A. A. (2019). Conundrums in the conscientious use of current best evidence. American Journal of Critical Care, 28(2), 93-95. https://doi.org/10.4037/ajcc2019686

Nair, H., Nokes, D. J., Gessner, B. D., Dherani, M., Madhi, S. A., Singleton, R. J., O’Brien, K. L., Roca, A., Wright, P. F., Bruce, N., Chandran, A., Theodoratou, E., Sutanto, A., Sedyaningsih, E. R., Ngama, M., Munywoki, P. K., Kartasasmita, C., Simões, E. A. F., Rudan, I., ... Campbell, H. (2010). Global burden of acute lower respiratory infections due to respiratory syncytial virus in young children: $A$ systematic review and meta-analysis. The Lancet, 375(9725), 1545-1555.

https://doi.org/10.1016/s0140-6736(10)60206-1

Nicolai, A., Ferrara, M., Schiavariello, C., Gentile, F., Grande, M., Alessandroni, C., \& Midulla, F. (2013). Viral bronchiolitis in children: A common condition with few therapeutic options. Early Human Development, 89, 7-11. https://doi.org/10.1016/j.earlhumdev.2013.07.016

O’Kelly, F., Nason, G. J., Manecksha, R. P., Cascio, S., Quinn, F. J., Leonard, M., Koyle, M. A., Farhat, W., \& Leveridge, M. J. (2017). The effect of social media (\#SoMe) on journal impact factor and parental awareness in paediatric urology. Journal of Pediatric Urology, 13(5), 513-513.

https://doi.org/10.1016/j.jpurol.2017.03.027

Ricci, V., Nunes, V. D., Murphy, M. S., \& Cunningham, S. (2015). Bronchiolitis in children: Summary of NICE guidance. BMJ, 350, h2305. https://doi.org/10.1136/bmj.h2305

Scott, A., Docking, S., Vicenzino, B., Alfredson, H., Zwerver, J., Lundgreen, K., Finlay, O., Pollock, N., Cook, J. L., Fearon, A., Purdam, C. R., Hoens, A., Rees, J. D., Goetz, T. J., \&amp; Danielson, P. (2013). Sports and exercise-related tendinopathies: A review of selected topical issues by participants of the second International Scientific Tendinopathy Symposium (ISTS) Vancouver 2012. British Journal of Sports Medicine, 47(9), 536-544. https://doi.org/10.1136/bjsports-2013-092329

Scott, S. D. [@echoKTresearch]. (n.d.). Tweets [Twitter profile]. Twitter. Retrieved December 6, 2021, from https://twitter.com/echoktresearch

Slater, M. D., Buller, D. B., Waters, E., Archibeque, M., \& LeBlanc, M. (2003). A test of conversational and testimonial messages versus didactic presentations of nutrition information. Journal of Nutrition Education and Behavior, 35(5), 255-259. https://doi.org/10.1016/s1499-4046(06)60056-0

Stevens, K. R. (2013). The impact of evidence-based practice in nursing and the next big ideas. The Online Journal of Issues in Nursing, 18(2), 4. https://doi.org/10.3912/0JIN.Vol18No02Man04

Translating Emergency Knowledge for Kids. (n.d.a). Home [Facebook page]. Facebook. Retrieved December 6, 2021, from https://www.facebook.com/TREKKca/

TREKK [@TREKKca]. (n.d.b).Tweets [Twitter profile]. Twitter. Retrieved December 6, 2021, from https://twitter.com/TREKKca?ref_src=twsrc\%5Egoogle\%7Ctwcamp\%5Eserp\%7Ctwgr\%5Eauthor 
Translating Emergency Knowledge for Kids. (2021a). Translating emergency knowledge for kids. https://trekk.ca/

Translating Emergency Knowledge for Kids. (2021b). Patient and family tools. https://trekk.ca/ healthconsumers

Tunnecliff, J., Ilic, D., Morgan, P., Keating, J., Gaida, J. E., Clearihan, L., Sadasivan, S., Davies, D., Ganesh, S., Mohanty, P., Weiner, J., Reynolds, J., \&amp; Maloney, S. (2015). The acceptability among health researchers and clinicians of social media to translate research evidence to clinical practice: Mixed-methods survey and interview study. Journal of Medical Internet Research, 17(5). https://doi.org/10.2196/jmir.4347

University of Alberta. (2021). Alberta Research Centre for Health Evidence. https://www.ualberta.ca/ pediatrics/pediatric-research/affiliated-research-units/alberta-research-centre-for-healthevidence-arche/index.html

Unnikrishnan, B., Rathi, P., Shah, D., Tyagi, A., Rao, A. V., Paul, K., \& Tomy, J. (2018). Perception among healthcare professionals of the use of social media in translating research evidence into clinical practice in Mangalore. International Journal of Telemedicine and Applications, 2018, 1-8. https://doi.org/10.1155/2018/7573614

Ventola C. L. (2014). Social media and health care professionals: Benefits, risks, and best practices. P\&T, 39(7), 491-520. https://www.ncbi.nIm.nih.gov/pmc/articles/PMC4103576/

Viviani, M., \& Pasi, G. (2017). Credibility in social media: Opinions, news, and health information-a survey. Wiley Interdisciplinary Reviews: Data Mining and Knowledge Discovery, 7(5), e1209.

https://doi.org/10.1002/widm.1209 